\title{
Solvent Extraction of DNA with a Hydrolysable Double-chain Surfactant
}

\author{
Yoshihiro Itoh, Ken Takahashi, and Yuichi Uemura \\ Department of Functional Polymer Science, \\ Faculty of Textile Science and Technology, \\ Shinshu University, Nagano, Japan
}

\begin{abstract}
A cationic lipophilic surfactant with two hydrolysable groups, di(1-octadecyloxycarbonylmethyl)dimethylammonium chloride, was synthesized and solvent extraction of deoxyribonucleotide (DNA) into organic solution (isooctane/1-octanol) with it as an extractant was examined. Not only forward extraction of DNA into organic phase but also back extraction into aqueous phase (pH >9) at room temperature proceeded efficiently. The forward extraction is promoted by electrostatic interactions of the surfactant and DNA and the back extraction is exclusively caused by hydrolysis of the surfactant to a non-surfactant.
\end{abstract}

Keywords: Cleavable surfactant, hydrolysis, solvent extraction, back extraction, DNA

Running title: Solvent Extraction of DNA

Address correspondence to Yoshihiro Itoh, Department of Functional Polymer Science, Faculty of Textile Science and Technology, Shinshu University, Ueda, Nagano 386-8567, Japan. E-mail: yositoh@shinshu-u.ac.jp 


\section{INTRODUCTION}

Solvent extractions with lipophilic surfactants, so-called reverse micellar extractions, have attracted much attention as efficient separation media for valuable or bioactive water-soluble materials $(1,2)$. In most cases, however, the recovery of substrates (or 'back extraction' into aqueous phase) under mild conditions are insufficient and many attempts to increase the efficiency have been made (3). It has been recently reported that DNA in aqueous solution can be extracted into organic phase quantitatively using a small amount $(<10 \mathrm{mM})$ of lipophilic quaternary ammonium surfactants (dialkyldimethylammonium salts: $2 \mathrm{C}_{\mathrm{n}} \mathrm{QA}$ ) as extractants, which is promoted mainly by electrostatic interaction between $2 \mathrm{C}_{n} \mathrm{QA}$ and DNA $(4,5)$. The authors also demonstrated that complete recovery of DNA into aqueous phase is achieved by adding moderate amounts of 1-butanol (17\% (v/v)) and $\mathrm{NaCl}(0.5 \mathrm{M})$ to unstabilize the 'complex' of 2C $\mathrm{C}_{\mathrm{n}} \mathrm{A}$ and DNA (5). Minimized contamination of such additives, however, is desirable for the practical uses because organic solvents and/or extractants should be separated and recycled easily in large-scale processes. Elimination of surface or ionic activities of the extractants in the back extraction process under mild conditions will be favorable for the separation.

In this context, cleavable surfactants that break down to non-surface active products seem to be promising. Hayes et al. recently reported efficient recovery of enzymes in water-in-oil microemulsions into aqueous phase $(\mathrm{pH}$ 5) with a acid-hydrolysable nonionic surfactant, though in a large amount $(>0.1 \mathrm{M})(6,7)$. Among various types of surfactants prepared so far (8), alkali-hydrolysable cationic surfactants with a betaine ester group (8-11) would be candidates for extractants of DNA because the surfactants decompose promptly at room temperature in weakly 
basic solution where DNA is relatively stable.

In the present paper, we report that a lipophilic double-chain surfactant with two hydrolysable groups, di(1-octadecyloxycarbonylmethyl)dimethylammonium chloride ( $2 \mathrm{C}_{18} \mathrm{BC}$ : Figure 1), can be used as an effective extractant which promotes separation of DNA under mild conditions.

\section{EXPERIMENTAL}

\section{Measurements}

${ }^{1} \mathrm{H}$ NMR, absorption, and circular dichroism (CD) spectra were recorded on a Bruker AVANCE400 spectrometer, a HITACHI U-3210 spectrophotometer, and a Jasco J-600 spectropolarimeter, respectively. Gas chromatography (GC) analysis was performed on a Shimadzu GC-8A equipped with a flame-ionization detector on an OV-17 column (5\% Uniport HP 80/100). 1-Hexadecanol was used as an internal standard.

\section{Materials}

DNA from salmon testes was purchased from Sigma-Aldrich Japan, Japan, and used as received. The molecular weight was determined to be around 1,500 $\mathrm{kDa}$ by agarose gel electrophoresis. $\quad$ Di(1-octadecyl)dimethylammonium bromide (2 $\left.\mathrm{C}_{18} \mathrm{QAB}\right)$ (Tokyo Kasei, Japan) was used without further purification.

1-Tetradecyloxycarbonylmethyltrimethylammonium chloride $\left(\mathrm{C}_{14} \mathrm{BC}\right)$ and 1-octadecyloxycarbonylmethyltrimethylammonium chloride $\left(\mathrm{C}_{18} \mathrm{BC}\right)$ were prepared 
by esterifications of 1-tetradecanol and 1-octadecanol, respectively, with chloroacetyl chloride followed by quaternization with trimethylamine $(10,11)$ : $\mathrm{C}_{14} \mathrm{BC}$; yield, $87 \%$; purity, 98\%: $\mathrm{C}_{18} \mathrm{BC}$; yield, 33\%; purity, 99\%.

$2 \mathrm{C}_{18} \mathrm{BC}$ was synthesized as follows: 1-Octadecyl dimethylglycinate was prepared by alkylation of dimethylamine with 1-octadecyl chloroacetate in benzene for $4 \mathrm{~h}$ at room temperature: white solid; yield, 72\%. 1-Octadecyl dimethylglycinate was quaternized with 1-octadecyl chloroacetate in acetone for one day at room temperature. The crude product was purified by precipitation from chloroform to $n$-hexane: white solid; yield, 65\%; purity, 99\%; ${ }^{1} \mathrm{H}$ NMR $\left(\mathrm{CDCl}_{3}\right) \delta 0.88$ (t, J=6.8 Hz, 6H, $\left.-\mathrm{CH}_{3}\right), 1.26$ (broad s, 60H, -( $\left(\mathrm{CH}_{2}\right)_{15}-$ ), 1.65 (m, 4H, - $\mathrm{CH}_{2}-\mathrm{CH}_{2}-\mathrm{OCO}-$ ), 3.85 (s, 6H, - $\mathrm{N}\left(\mathrm{CH}_{3}\right)_{2}$ ), 4.17 (t, J=6.9 Hz, 4H, -CH $2-\mathrm{OCO}-), 5.18$ (s, 4H, -OCO-CH$-\mathrm{N}-$ ).

\section{Forward Extraction and Back extraction}

Extraction experiments of DNA were carried out according to the method of Goto et al. $(4,5)$ with some modification. A typical procedure is as follows: A $5 \mathrm{ml}$ of aqueous solution of DNA (50 $\mu \mathrm{g} / \mathrm{ml})$ in $10 \mathrm{mM}$ phosphate buffer ( $\mathrm{pH}$ 7) was placed in a $15 \mathrm{ml}$ of test tube. A $5 \mathrm{ml}$ of surfactant solution $(2 \mathrm{mM})$ in isooctane/1-octanol (v/v=94/6) was added and shaken in a water bath (TAIYO Incubator M-100N) at $25^{\circ} \mathrm{C}$ for $1 \mathrm{~h}$. A $3 \mathrm{ml}$ of the extracted organic solution was then transferred into another tube and shaken with a $3 \mathrm{ml}$ of aqueous buffer solution (20 mM: $\mathrm{pH} 7-12)$ for $2 \mathrm{~h}$ : $\mathrm{KH}_{2} \mathrm{PO}_{4}-\mathrm{NaOH}$ (pH 6-8), $\mathrm{KH}_{2} \mathrm{PO}_{4}$-borax ( $\mathrm{pH}$ 7-9), $\mathrm{H}_{3} \mathrm{BO}_{3}-\mathrm{NaOH}$ (pH 9-10), glycine- $\mathrm{NaOH}$ ( $\mathrm{pH}$ 9-12), and $\mathrm{Na}_{2} \mathrm{HPO}_{4}-\mathrm{NaOH}$ (pH 11-12) were used as buffers. Forward extraction and back extraction yields were determined from the absorbance change at $260 \mathrm{~nm}$ in the aqueous and organic phases, respectively. The experiments 
expect for the $\mathrm{pH}$ dependence on the back extraction (Figure 4) were at least duplicated. The reproducibility of the forward extraction was within $5 \%$ and that of the back extraction was within $10 \%$.

\section{Hydrolysis}

To the organic phase containing $2 \mathrm{C}_{18} \mathrm{BC}$ before and after the back extraction a $0.1 \mathrm{ml}$ of $1 \mathrm{M}$ aqueous $\mathrm{HCl}$ was added to terminate the hydrolysis. To a $1 \mathrm{ml}$ of the solution 1-hexadecanol (2 mM) in $1 \mathrm{ml}$ of $n$-hexane was added as an internal standard and then directly injected into a GC instrument. Hydrolysis yields were determined from the yield of a hydrolyzed product, 1-octadecanol.

\section{RESULTS AND DISCUSSION}

\section{Forward Extraction}

For forward extraction of DNA, hydrolysable and non-hydrolysable surfactants, $2 \mathrm{C}_{18} \mathrm{BC}$ and $2 \mathrm{C}_{18} \mathrm{QAB}$ (Figure 1), were used as extractants. Isooctane containing 1-octanol, as a co-solvent which improves the surfactant solubilities, was used as an organic phase according to the results of Goto et al. (4): both $2 \mathrm{C}_{18} \mathrm{BC}$ and $2 \mathrm{C}_{18} \mathrm{QAB}$ in concentration up to $10 \mathrm{mM}$ appeared to dissolve in isooctane/1-octanol ( $\mathrm{v} / \mathrm{v}=94 / 6)$.

Figure 2 shows the extraction of DNA into organic phase as a function of extraction (shaking) time at $\mathrm{pH}$ 7. Using a $10 \mathrm{mM}$ phosphate buffer solution as the aqueous phase, almost $100 \%$ extraction was achieved within 30 min for both 
$2 \mathrm{C}_{18} \mathrm{QAB}$ and $2 \mathrm{C}_{18} \mathrm{BC}$. In contrast, extractions from the Tris-HCl buffer solutions were incomplete. The yield of ca. $80 \%$ for $2 \mathrm{mM}$ of $2 \mathrm{C}_{18} \mathrm{QAB}$ agreed with the value reported by Goto et al. (5). Since the extraction is promoted by electrostatic interaction between cationic surfactants and DNA (polyanion) $(4,5)$, interaction of Tris-HCl (organic cation) and DNA might retard the DNA transfer. The fact that the addition of $80 \mathrm{mM} \mathrm{NaCl}$ to the phosphate buffer solution containing $2 \mathrm{C}_{18} \mathrm{BC}$ decreased the yield to $46 \%$ indicates the contribution of electrostatic interaction to the extraction. We also note that the extraction yields from the phosphate buffer solution with the corresponding surfactants with a monoalkyl chain, $\mathrm{C}_{14} \mathrm{BC}$ and $\mathrm{C}_{18} \mathrm{BC}$, were only $3 \%$ and $47 \%$, respectively. This clearly indicates an additional and important role of the hydrophobicities of $2 \mathrm{C}_{18} \mathrm{QAB}$ and $2 \mathrm{C}_{18} \mathrm{BC}$ in the extraction (5).

\section{Back Extraction}

Figure 3 shows the back extraction of DNA into aqueous phase as a function of back extraction (shaking) time at $\mathrm{pH}$ 11. DNA in the organic phase containing $2 \mathrm{C}_{18} \mathrm{QAB}$ could not be transferred to the aqueous phase. On the other hand, the back transfer of DNA from the organic phase containing $2 \mathrm{C}_{18} \mathrm{BC}$ proceeded smoothly in $1 \mathrm{~h}$, and ca. $75 \%$ of DNA was recovered. These results clearly indicate that efficient alkali-hydrolysis of $2 \mathrm{C}_{18} \mathrm{BC}$ to a non-surfactant destabilizes the 'surfactant-DNA complex', promoting the release of DNA to aqueous phase. Figure 4 shows the $\mathrm{pH}$ dependence on the back extraction from the organic phase containing $2 \mathrm{C}_{18} \mathrm{BC}$. Although the value varied in different buffer solutions at the same $\mathrm{pH}$, the back extraction yield increased around $\mathrm{pH} 9$ and reached to almost $100 \%$ at $\mathrm{pH} 12$. It should be noted that after the complete back extraction the organic phase will hold 
only a small amount of 1-octadecanol (4 mM), a hydrolyzed product, and the aqueous buffer solution will contain a di(carboxymethyl)dimethylammonium salt (2 mM) as well as DNA (50 $\mu \mathrm{g} / \mathrm{ml})$.

It is known that hydrolysis of surface-active betaine esters in aqueous solution is accelerated by 'micellar catalysis', which is due to the locally elevated concentration of hydroxide ion caused by electrostatic attraction to the positively charged micelle surface (8-11). If this is also the present case, the increase of ionic strength in the aqueous phase would retard the hydrolysis of $2 \mathrm{C}_{18} \mathrm{BC}$ in the organic phase and thus the back extraction of DNA. We should also consider the possibility that the increased ionic strength decreases the electrostatic interaction of the cationic surfactant and DNA, facilitating the DNA transfer (5). As shown in Figure 3, the back extraction yield decreased at high buffer $(100 \mathrm{mM})$ and $\mathrm{NaCl}(80 \mathrm{mM})$ concentrations. Thus the hydrolysis of $2 \mathrm{C}_{18} \mathrm{BC}$ to a non-surfactant is crucial to the back extraction efficiency.

It is, however, unexpected that after the back extraction (total time of extraction and back extraction, 3 h) $2 \mathrm{C}_{18} \mathrm{BC}$ of a large quantity was hydrolyzed even at neutral $\mathrm{pH}$ where DNA was little transferred to the aqueous phase: the hydrolysis and back extraction yields at $\mathrm{pH} 7$ (phosphate buffer) were $83 \%$ and $2 \%$, respectively. The result is in contrast to the fact that the corresponding water-soluble betaine ester, $\mathrm{C}_{14} \mathrm{BC}$, is not hydrolyzed in aqueous solution below $\mathrm{pH} 8$ (11). Although we have no clear reasons for the difference, there seems to be some points to be taken into consideration for the high hydrolysity of $2 \mathrm{C}_{18} \mathrm{BC}$ and the low back extraction yield of DNA here. As for the high hydrolysity, first, the $2 \mathrm{C}_{18} \mathrm{BC}$ molecules located dominantly at the oil-water interface might be extremely susceptible to hydrolysis by the 'micellar catalysis' described above: the increased concentration of hydroxide ion 
at the cationic interface facilitates the nucleophilic attack by hydroxide ion at the carbonyl carbon of $2 \mathrm{C}_{18} \mathrm{BC}$ to cleavage its ester bonds under mild condition. In addition, the strongly electron-withdrawing quaternary ammonium group has further facilitating effect on the attack (8-10). The former 'catalyst' effect was confirmed by the fact that ca. $70 \%$ of $2 \mathrm{C}_{18} \mathrm{BC}$ was hydrolyzed within $5 \mathrm{~min}$ in the absence of DNA at $\mathrm{pH} 7$ and the addition of $80 \mathrm{mM} \mathrm{NaCl}$ decreased the hydrolysis yield to 6\%. As for the low back extraction yield at $\mathrm{pH} 7$, second, since $2 \mathrm{C}_{18} \mathrm{BC}$ cations $(2 \mathrm{mM})$ are estimated to be large excess (more than at least 10 fold) to phosphate anions in DNA under the present condition, the 'surfactant-DNA complex' may still remain after the hydrolysis of $2 \mathrm{C}_{18} \mathrm{BC}$ up to $90 \%$ yield, inhibiting the back extraction: a $50 \mu \mathrm{g} / \mathrm{ml}$ of DNA is estimated to have far less than $0.2 \mathrm{mM}$ of anions and $2 \mathrm{C}_{18} \mathrm{BC}$ after the $90 \%$ hydrolysis (larger than $83 \%$ at $\mathrm{pH}$ 7) will still have $0.2 \mathrm{mM}$ of ammonium groups, retaining the electrostatic attraction of DNA and $2 \mathrm{C}_{18} \mathrm{BC}$.

Preliminary experiments for the improved process efficiency showed that decreasing the solution $\mathrm{pH}$ to 6 retained the extraction yield of $100 \%$ and decreased the hydrolysis yield after the back extraction to $60 \%$ and that the addition of $20 \mathrm{mM}$ $\mathrm{NaCl}$ to the $\mathrm{pH} 6$ solution decreased the extraction and hydrolysis yields to $90 \%$ and $30 \%$, respectively. Based on these results, the optimizations of the extraction condition without any hydrolysis of $2 \mathrm{C}_{18} \mathrm{BC}$ and the back extraction condition with minimized additives are being examined.

\section{Stability of DNA}

It is important to assess the stability of DNA in the forward and back extraction processes. Figure 5 shows the absorption and CD spectra of DNA in aqueous phases 
before forward extraction and after back extraction. Both spectra were affected only slightly in the processes, implying little denaturation of DNA under the present condition. In addition, no apparent fragmentation of DNA was observed by agarose gel electrophoresis. Therefore, DNA in aqueous solution will be safely transferred into another water phase by solvent extraction, as reported previously (5).

\section{CONCLUSIONS}

It has been demonstrated that a cationic lipophilic betaine ester $\left(2 \mathrm{C}_{18} \mathrm{BC}\right)$ can extract DNA almost quantitatively into organic phase and back-extract it efficiently into aqueous phase not only under mild conditions but also without large amounts of additives. If the back extraction achieved the $100 \%$ yield, the organic phase after the back extraction, containing only a small amount of non-surfactant (1-octadecanol: 4 $\mathrm{mM}$ under the present condition), will be easily reused or recycled. Although mechanistic details of the back extraction process have not been clarified yet, it can be safely said that this type of lipophilic surfactants are used as efficient solvent extractants for water-soluble ionic species.

\section{NOMENCLATURE}

$2 \mathrm{C}_{\mathrm{n}} \mathrm{QA} \quad$ dialkyldimethylammonium salt

2 $\mathrm{C}_{18} \mathrm{QAB} \quad$ di(1-octadecyl)dimethylammonium bromide

$2 \mathrm{C}_{18} \mathrm{BC} \quad$ di(1-octadecyloxycarbonylmethyl)dimethylammonium 
chloride

$\mathrm{C}_{14} \mathrm{BC}$ 1-tetradecyloxycarbonylmethyltrimethylammonium chloride

$\mathrm{C}_{18} \mathrm{BC} \quad$ 1-octadecyloxycarbonylmethyltrimethylammonium chloride

DNA deoxyribonucleotide

CD $\quad$ circular dichroism

GC gas chromatography

\section{ACKNOWLEDGEMENTS}

This work was supported by a Grant-in-Aid for 21st Century COE Program and a Grant-in-Aid for Global COE Program from the Ministry of Education, Culture, Sports, Science, and Technology of Japan.

\section{References}

1. Pires, M.J.; Aries-Barros, M.R.; Cabral, J.M.S. Liquid-liquid extraction of proteins with reversed micelles. Biotechnol. Prog. 1996, 12 (3), 290.

2. Rydberg, J.; Cox, M.; Musikas, C.; Choppin G.R. Eds. Solvent Extraction Principles and Practice, 2nd Ed.; Marcel Dekker: New York, 2004.

3. Mathew, D.S.; Juang, R.-S. Role of alcohols in the formation of inverse microemulsions and back extraction of proteins/enzymes in a reverse micellar system. Sep. Purif. Technol. 2007, 53 (3), 199.

4. Goto, M.; Ono, T.; Horiuchi, A.; Furusaki, S. Extraction of DNA by reversed 
micelles. J. Chem. Eng. Jpn. 1999, 32 (1), 123.

5. Goto, M.; Momota, A.; Ono, T. DNA extraction by cationic reverse micelles. J. Chem. Eng. Jpn. 2004, 37 (5), 662.

6. Iyer, M.; Hayes, D.G.; Harris, J.M. Synthesis of pH degradable nonionic surfactants and their applications in microemulsions. Langmuir 2001, 17 (22), 6816.

7. Rairkar, M.E.; Hayes, D.G.; Harris, J.M. Solubilization of enzymes in water-in-oil microemulsions and their rapid and efficient release through use of a pH-degradable surfactant. Biotechnol. Lett. 2007, 29 (5), 767.

8. Stjerndahl, M.; Lundberg, D.; Holmberg, K. Cleavable surfactants, in: Holmberg K. Ed. Novel Surfactants: Preparation, Applications, and Biodegradability, 2nd Ed.; Surf. Sci. Ser. 114; Marcel Dekker: New York, 2003, pp. 317.

9. Thompson, R.A.; Allenmark, S. Factors influencing the micellar catalyzed hydrolysis of long-chain alkyl betainates. J. Colloid Interface Sci. 1992, 148 (1), 241.

10. Lundberg, D.; Holmberg, K. Nuclear magnetic resonance studies on hydrolysis kinetics and micellar growth in solutions of surface-active betaine esters. J. Surf. Det. 2004, 7 (3), 239.

11. Itoh, Y.; Akasaka, R.; Takahashi, K. Preparation of emulsifier-free polystyrene by conventional emulsion polymerization with a hydrolysable emulsifier. J. Appl. Polym. Sci. 2008, 108 (1), 358. 


\section{Figure Captions}

Figure 1. Chemical structures of $2 \mathrm{C}_{18} \mathrm{BC}$ and $2 \mathrm{C}_{18} \mathrm{QAB}$.

Figure 2. Time course of DNA extraction from aqueous buffer solutions into organic solutions containing surfactants (isooctane/1-octanol $(\mathrm{v} / \mathrm{v}=94 / 6))$ at $25^{\circ} \mathrm{C}$ : [DNA] $=50$ $\mu \mathrm{g} / \mathrm{ml}$; [surfactant]=2 mM; [buffer]=10 mM; open symbols, $\mathrm{KH}_{2} \mathrm{PO}_{4}-\mathrm{NaOH}$ buffer ( $\mathrm{pH} 7$ ); closed symbols, Tris- $\mathrm{HCl}$ buffer ( $\mathrm{pH} 7$ ); circle, $2 \mathrm{C}_{18} \mathrm{QAB}$; triangle, $2 \mathrm{C}_{18} \mathrm{BC}$; square, no surfactant.

Figure 3. Time course of DNA back extraction from organic solutions into aqueous glycine- $\mathrm{NaOH}$ buffer solutions $\left(\mathrm{pH} 11\right.$ ) at $25^{\circ} \mathrm{C}$ : circle, $2 \mathrm{C}_{18} \mathrm{QAB}$; triangle, $2 \mathrm{C}_{18} \mathrm{BC}$; open symbols, 20 mM buffer; closed symbol (triangle), 100 mM buffer; closed symbol (reverse triangle), $20 \mathrm{mM}$ buffer $+80 \mathrm{mM} \mathrm{NaCl}$.

Figure 4. $\mathrm{pH}$ dependence on DNA back extraction from organic solutions containing $2 \mathrm{C}_{18} \mathrm{BC}$ into aqueous buffer solutions at $25{ }^{\circ} \mathrm{C}$ : [buffer] $=20 \mathrm{mM}$; circle, $\mathrm{KH}_{2} \mathrm{PO}_{4}-\mathrm{NaOH}$ ( $\mathrm{pH}$ 6-8); triangle, $\mathrm{KH}_{2} \mathrm{PO}_{4}$-borax ( $\mathrm{pH}$ 7-9); square, $\mathrm{H}_{3} \mathrm{BO}_{3}-\mathrm{NaOH}$ (pH 9-10), reverse triangle, glycine- $\mathrm{NaOH}$ ( $\mathrm{pH}$ 9-12); diamond, $\mathrm{Na}_{2} \mathrm{HPO}_{4}-\mathrm{NaOH}$ buffer (pH 11-12); back extraction time, 2 h.

Figure 5. Absorption (a) and CD (b) spectra of DNA in aqueous phases before forward extraction (solid line) and after back extraction (dotted line): [DNA]=50 $\mu \mathrm{g} / \mathrm{ml} ; \quad\left[2 \mathrm{C}_{18} \mathrm{BC}\right]=2 \mathrm{mM} ; \quad\left[\mathrm{KH}_{2} \mathrm{PO}_{4}-\mathrm{NaOH}\right.$ buffer $]=10 \quad \mathrm{mM}$ (before: $\mathrm{pH}$ 7); [glycine- $\mathrm{NaOH}$ buffer]=20 mM (after: $\mathrm{pH} 11$ ); CD spectra were corrected for the absorbance. 


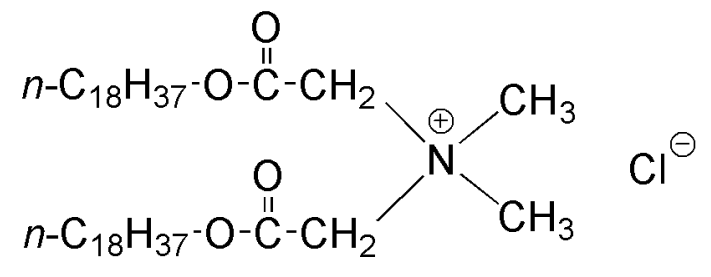

$2 \mathrm{C}_{18} \mathrm{BC}$

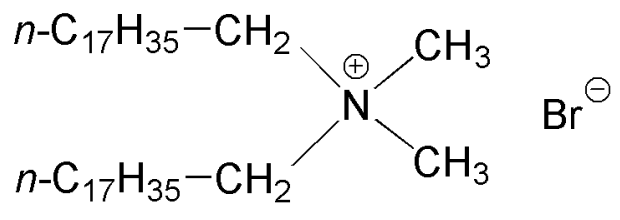

$2 C_{18} Q A B$

Figure 1. Chemical structures of $2 \mathrm{C}_{18} \mathrm{BC}$ and $2 \mathrm{C}_{18} \mathrm{QAB}$.

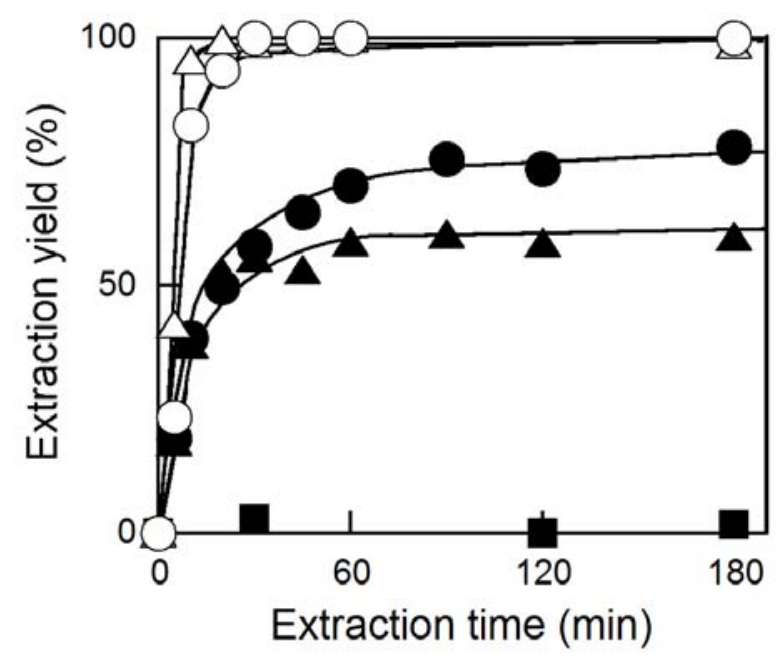

Figure 2. Time course of DNA extraction from aqueous buffer solutions into organic solutions containing surfactants (isooctane/1-octanol $(\mathrm{v} / \mathrm{v}=94 / 6))$ at $25^{\circ} \mathrm{C}$ : [DNA] $=50$ $\mu \mathrm{g} / \mathrm{ml}$; [surfactant]=2 mM; [buffer]=10 mM; open symbols, $\mathrm{KH}_{2} \mathrm{PO}_{4}-\mathrm{NaOH}$ buffer ( $\mathrm{pH} 7$ ); closed symbols, Tris- $\mathrm{HCl}$ buffer ( $\mathrm{pH} 7$ ); circle, $2 \mathrm{C}_{18} \mathrm{QAB}$; triangle, $2 \mathrm{C}_{18} \mathrm{BC}$; square, no surfactant. 


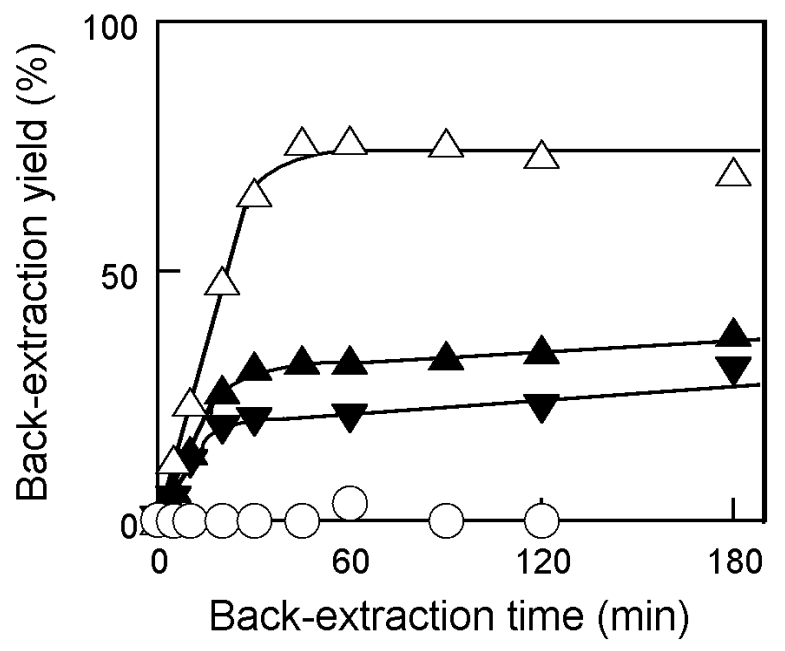

Figure 3. Time course of DNA back extraction from organic solutions into aqueous glycine- $\mathrm{NaOH}$ buffer solutions ( $\mathrm{pH} 11)$ at $25{ }^{\circ} \mathrm{C}$ : circle, $2 \mathrm{C}_{18} \mathrm{QAB}$; triangle, $2 \mathrm{C}_{18} \mathrm{BC}$; open symbols, $20 \mathrm{mM}$ buffer; closed symbol (triangle), $100 \mathrm{mM}$ buffer; closed symbol (reverse triangle), $20 \mathrm{mM}$ buffer $+80 \mathrm{mM} \mathrm{NaCl}$.

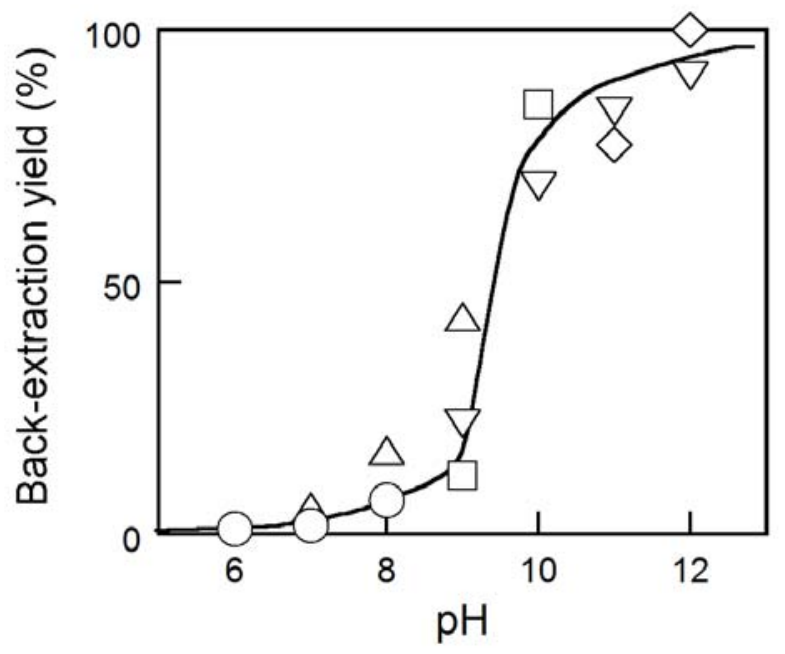

Figure 4. $\mathrm{pH}$ dependence on DNA back extraction from organic solutions containing $2 \mathrm{C}_{18} \mathrm{BC}$ into aqueous buffer solutions at $25{ }^{\circ} \mathrm{C}$ : [buffer] $=20 \mathrm{mM}$; circle, $\mathrm{KH}_{2} \mathrm{PO}_{4}-\mathrm{NaOH}\left(\mathrm{pH}\right.$ 6-8); triangle, $\mathrm{KH}_{2} \mathrm{PO}_{4}$-borax ( $\mathrm{pH}$ 7-9); square, $\mathrm{H}_{3} \mathrm{BO}_{3}-\mathrm{NaOH}$ ( $\mathrm{pH}$ 9-10), reverse triangle, glycine- $\mathrm{NaOH}$ ( $\mathrm{pH}$ 9-12); diamond, $\mathrm{Na}_{2} \mathrm{HPO}_{4}-\mathrm{NaOH}$ buffer (pH 11-12); back extraction time, 2 h. 

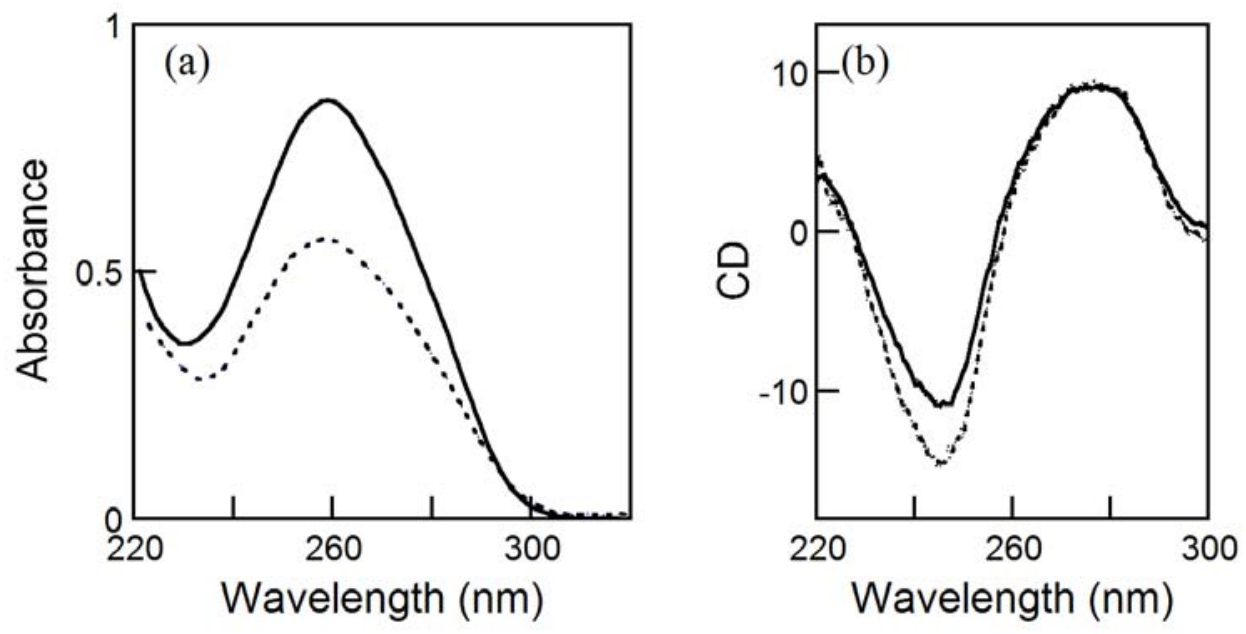

Figure 5. Absorption (a) and CD (b) spectra of DNA in aqueous phases before forward extraction (solid line) and after back extraction (dotted line): [DNA] $=50$ $\mu \mathrm{g} / \mathrm{ml} ; \quad\left[2 \mathrm{C}_{18} \mathrm{BC}\right]=2 \mathrm{mM}$; $\quad\left[\mathrm{KH}_{2} \mathrm{PO}_{4}-\mathrm{NaOH}\right.$ buffer $]=10 \mathrm{mM}$ (before: $\mathrm{pH}$ 7); [glycine- $\mathrm{NaOH}$ buffer]=20 mM (after: $\mathrm{pH} 11$ ); $\mathrm{CD}$ spectra were corrected for the absorbance. 